\title{
Governing Pudahuel: Applying Regime Analysis to a Chilean Study Case
}

\author{
Juan Pablo Astorga del Río \\ Universidad Central de Chile \\ Manuel del Campo Munnich \\ Universidad Central de Chile
}

\begin{abstract}
This research uses Urban Regime Theory and identifies one in Pudahuel, Chile. It examines the process through which the public-private agreements and a strategic agenda were organized to develop urban and social policies in Pudahuel commune through local actors between 1994 and 2010. Given the lack of decentralized planning in Chile and taking advantage of a change in the balance of power in Pudahuel, local actors imagined and produced environmental and social policies based on their local reality. And concluded the process with a local masterplan, mainly financed by the private sector. The process develops a model of urbanization through compensation. However, this does not guarantee full citizen participation, effective alternatives to segregation nor balanced development. The analysis also serves as an indicator of how effective the central government is in directing the urban economy. The Pudahuel regime was eventually used as a model for national urban programs; both reductionist models of the initial meaning of producing urban policies through compensation that consider local environmental conflicts.
\end{abstract}

Keywords: governance, urban regimes, regional planning, compensation, Pudahuel

\section{INTRODUCTION}

This research uses Regime Theory to evaluate whether an Urban Regime can be identified in Pudahuel, Chile. The research examines the process through which agreements and a strategic agenda were set up to develop Pudahuel commune by relevant local actors between 1994 and 2010. The case has several clear and evident Regime characteristics, such as interdependencies, cross-sector foundation, informal arrangements, and creation of trusts over time. Nevertheless, in-depth research is required to assure whether an Urban Regime can be identified in this process. Using Holman's comparative framework (2007), the "less visible aspects of governing arrangements at the local level" (p.440) have been recognized. This framework guides the research through several steps, starting with the external and historical factors; selection of relevant events surrounding the evolution of the coalition; impact of the coalition; and finally, evaluation of the case. The sections suggest the study case is a Regime, and the coalition's capacity to turn its relevant issues into common purposes, as well as into action (Stone, 2001) can be considered as strong. Nevertheless, some unresolved conflicts during the process may become the weakening links which eventually reduced the coalition's capacity to adapt to changing circumstances (Stone, 2001). Although 26 years have passed, some of the coalition's objectives have not concluded, therefore more time is needed to accurately evaluate the impacts. The analysis also serves as an indicator of how effective central 
government is in guiding the urban economy (Harding, 1997) of Santiago, the capital of Chile. Additionally, these studies also allow us detecting aspects that may point towards a shift from government to governance (John, 2001).

\section{Theoretical Discussion}

Since the mid-nineties Regime theory has become a dominant approach to studying urban politics (Newman \& Thornley 2005; Davies, 2003; Holman 2007; Harding 1997). Considering that the original context of regime theory is the US, much of the discussion is centered on whether the theory can be applied to the UK, (Davies, 2003) and Europe. The starting point for the regime analysis is that there exists in a city a set of government institutions in the hands of popular control, and that the economy is mainly controlled by the private sector. Since ownership of relevant assets for growth is in the hands of business elites, governments establish a set of arrangements which will allow them to carry out their political commitments (Davies, 2003). The arrangements are achieved not by formal hierarchies, but by networking, in which actors cooperate because they recognize their mutual dependency to achieve goals. Without being forced to collaborate, negotiations and agreements take place, where a common or identifying agenda is created.

According to Harding (1997), using Regime Theory for cross national analysis requires paying attention to the power of communities. The idea of how externally imposed structures, through economic processes for example, predispose local actors to behave in a specific form highlights the geographical confinement of community action or power. Davies (2003), for example, points out the issue regarding how artificially induced collaboration may not create embedded coalitions. From almost the opposite perspective, Harding's (1997) "power of places" (p.294) reveals the importance of understanding how interest groups within localities build up governing power to control relevant productive activities. Holman (2007), for example, evidence how, after years of exposure to regional and global forces, a dynamic coalition capable of creating positive outcomes emerged from Portsmouth UK. John (2001) considers many coalitions to be significant players in determining policies, but stresses they work in different ways. These key differences are their aims; motivation of participants; the sense of common purpose; quality of coalition; and wider relationship with the local policy environment. Nevertheless, John (2001) also considers that the main members of a regime are the business elite, even if there are many different actors within the coalition. regime analysis may help to understand the nature of local decision making, and how external factors react to, or affect, these collaborative organizations. The theory also questions central and supranational agencies' capacity to induce local economic and social development, especially when technological diffusion, knowledge of local setting, choosing the optimal mix of measures and appropriate instrument may be achieved if drawn from the local scale and used for policy creation. (Viesti, 2002)

Regarding the theory's capacity to address different contexts, Davies (2003) considers that applying regime theory is concept-stretched within the UK, where cases of public-private collaboration should be considered short-term partnerships instead of inclusive long-term regimes ${ }^{1}$. He suggests three reasons why urban regimes are unlikely to appear in the UK context. Firstly, a strong internal dynamic is necessary to sustain collaboration. Without a material interdependence between political and economic elites, the weakness of collaboration will undermine the necessary dynamics. Secondly, the US has a long-lasting tradition of collaborating in local politics that is not necessarily the case in other contexts. Thirdly, without decentralization of political power and control over resources, it is improbable that the other conditions will prevail. In general Davies focuses on programs that reveal how national governments try to induce collaboration at the local level.

Newman \& Thornley (2005) consider regime theory useful in examining city governance beyond the US and UK context. This appreciation relies on the "flexibility and ability to address variety" of the theory (p.45), being this argument relevant to support the use of regime theory outside US context. They identify two key questions when using regime analysis. The first one is if a regime is identifiable, and the second is if its capacity to act is weak or strong. The second question is related to Stone's concept of issue framing (2001), or "... how issue concerns come to be specified as purposes, and how they are linked, enlarged and refined for action" (p.20). The coalition's capacity to adapt to changing circumstances may evolve, 
maintaining or losing effectiveness in time. Not less relevant is also identifying what specific purpose the governing coalition has and what has made it successful. Newman \& Thornley (2005), consider the competitive climate in which urban decision making takes place make it necessary to explore how the actors interpret this environment, and how this "leads into particular forms of urban governance". They add that, given the belief that globalization leads to greater autonomy of action at the city level, the community power debate from the USA, usually considered less relevant in other cities in the world because they lack autonomy, may become increasingly relevant. Finally, they point out that Regime Theory is considered a useful exercise whether or not a regime is found that matches those in the original US context".

On the other hand, Nancy Holman (2007) in response to Davies' (2003) argument considers that focusing on specific central government-driven programs is insufficient to understand the "long-term, less visible features of business participation in local governing arrangements that might point towards regime". (p.435) She questions the sense of guiding the discussion towards weakening the theory's comparative potential. Additionally, as Newman \& Thornley (2005) point out, context may change in time, and in the case of Portsmouth, regime analysis helps to evidence how the macroeconomic processes "push down" (Harding, 1997) or give power to localities. Harding (1997) argues that regime analysis makes it easier to link to other literature related to local economic policy, where authors such as G. Viesti (2002) are keen to evidence that scale and intergovernmental relations matter, and that locality contains what it takes to implement efficient national and supranational socio-economic policies.

Regime Theory is used to understand why so many key regime characteristics are identified in the governing coalition of Pudahuel. According to Stone (1989), a regime's governing decisions are not a problem of running and controlling everything but have to do with "...managing conflict and making adaptive responses to social change..." (p.6). This point is important because the persisting environmental conflicts within Pudahuel required a different response, one which mobilized local actors to rearrange the distributive aspects of their productive assets. To understand why a collaborative form of decision making emerged in Pudahuel, Regime Theory becomes useful due to its capacity to explain the "accommodation between levels of government, and between public and private sectors in promoting urban economic innovation" (Harding, 1997). Regimes are more of an exception than a generalized form of governance (Holman 2007; John 2001; Davies 2003), and do not appear where conditions apparently should stimulate such reactions. Pudahuel's exceptional circumstances are discussed further in this research. Nevertheless, Pudahuel's coalition evidence a move from government to governance (John, 2001), where the local political system becomes less institutionalized, with closer relationships with private sector and increasing fragmentation of local service delivery.

During the nineties, one of the main critiques to Chile's urban development models was its lack of sustainability (Orozco, 2015; Vicuña del Río, 2017). It was during this decade that Pudahuel's regime became known by the government and considered as a successful example of a balanced urban growth. Eventually, the central government used the experience in Pudahuel as a basis to justify the creation of the PDUC (Projects with development conditions) and ZODUC (Zones with development conditions) programs to modernize Chilean urban policy. According to Orozco (2015) PDUC and ZODUC were means to greenwash market-based urban development model. For Vicuña del Río (2013), one of the main objectives of both national programs was to encourage land markets and control the impacts of projects through mitigation. And their studies indicate these programs encouraged negotiations among public and private actors (known as informal agreements in regime theory) towards ad hoc and place-specific agreements. Nonetheless, research suggests these public-private models predefine a list of compensations without making it clear during the negotiation process how the local population participates. What was supposed as a successful translation of a local Chilean-made model originated in Pudahuel, today research evidence it has lost its initial objective: a sustainable urban production, based on a participatory system that allows the local population to imagine and produce a city.

It is clear among these authors that ZODUC and PDUC's are one of the main housing solutions: creating well services places, sharing spaces among low, middle, and high-income groups. They also acknowledge both programs are a step forward in urban policies. But, so far, none of the investigations 
have reviewed the origin of the model, its initially participatory nature, nor questioned what happened in the transition from local model to national programs with participation. It is precisely the urban regime analysis that allows to build this evidence, thus contributing to the literature by researching the origins of the model. This research suggests local and environmental organizations observed constantly the agreement process between the municipality and business elite. But their influence decreased: mitigation or compensation agreements eventually took place primarily behind closed doors. However, when upgrading Pudahuel's participatory experience to the PDUC and ZODUC national models, participation was lost in translation.

\section{Methodology}

To understand whether Pudahuel's process is an Urban Regime, a selection of events and facts must be carried out to evaluate the case. The selection of events is based on the ten points that Nancy Holman (2007) developed to examine Portsmouth, $\mathrm{UK}^{2}$. (See appendix 2) These points "offer a focus on the less visible aspects of governing arrangements at the local level" that reflect the capacity generated by power (p.440). To not sidestep or fall into concept stretching, she considers three aspects as highly relevant: a well-targeted case, the mode of scrutiny, and the context of local governing arrangements (2007).

In reference to the selection of the case, Pudahuel has most of its economic assets in the hands of a few business leaders, which makes the local government dependent on this local elite to achieve its political commitments (Davies, 2005). Applying the theory requires successive steps, such as contextualization, selection of events, and evaluation; steps that are present throughout this paper. Additionally, exploring this local context reveals two aspects that constantly appear in regime study cases: the permeability (Kantor \& Savitch, 2005) to higher governmental tiers, and vulnerability to global forces; both refer to different scales of decision making which constantly interact and evolve, just as regimes do (Stone, 2001; Newman \& Thornley, 2005). The study case was initially selected by its initial characteristics and potential for regime analysis. And the analysis proves Regime Theory as highly useful to understand the nature of the local coalition and the set of factors that transformed Pudahuel.

One of the stressing issues for scholars in using comparative frameworks (Harding, 1997; John, 2001; Davies, 2003; Kantor \& Savitch 2005; Holman, 2007) is how to make generalization about places when comparing them, reducing complex and highly differentiated realities to a few common indicators. According to Kantor \& Savitch, (2005) a comparative framework should "be able to address issues that have similar meaning in a broad variety of political contexts and draw useful generalizations about the nature of the problem." Conceptual tools facilitate the filtering and selecting information process required to avoid the ethnocentric selection or interpretation issue (Kantor \& Savitch, 2005). From this perspective, Holman's framework allows a more detailed examination of cases based on ten accurate conceptual tools, as articulated by Clarence Stone" (Holman, 2007). This framework specifies key variables that allow us to be less concerned with institutional differences, and to focus more on important factors common to our selected cities (Kantor \& Savitch, 2005). In this research the selection Holman's conceptual framework is used to examine one study case, and not to compare various ones as other authors have, therefore the task is to leave the case conceptually open ended for eventual comparative analysis.

The research has been organized in three broad sections. The introduction, theoretical framework, and methodology compose the first section. The Second section, contextualization, is divided into four sub sections, each one baring a different approach to the case based in the need to systematize the analysis. The exogenous and endogenous subsection examines the exogenous forces that affected the creation of the coalition, contextualizing the case from a political and environmental perspective. To understand who cooperates, how cooperation began and the evolution of events (Stone, 1989), the second sub section, chronology of events, presents the events and facts chronologically. After researching a diversity of sources, as specific number of events were selected, this gave the basis to evaluate the process and its outcomes. The third subsection, impacts, focuses on the impacts of the coalition over the commune and city, emphasizing the evaluation of its strength. And the final sub section discusses the findings by analyzing each of the ten points separately, to make it as clear as possible whether Pudahuel's process is a Regime. This way the reader is guided through the process of applying the methodology and not just its findings. 
Finally, the third section presents the conclusions of the research, giving a conceptualized perspective of the study case.

There are general and specific research questions that guide this research. Newman \& Thornley (2005) have identified the two general questions. The first general question is whether an Urban Regime is identified in Pudahuel. Given that 26 years can be considered enough time to expect an evolution of the coalition, the second general question is whether the coalition is strong or weak today. The coalition has passed through several stages, and today apparently resides in Codesup, a nonprofit organization within Pudahuel, therefore the specific questions have to do with understanding how it works, and under which circumstances it was formed, because this may shed light over how and who governs Pudahuel today.

The events of the coalition occurred between 1994 and 2010, which gives a reasonable amount of time to observe an evolution in the coalition, identify the stable characteristics, evaluate its strength, and foresee its possible orientation in the future. Most of the documents that evidence its creation and growth have been written within Pudahuel. To create a chronology of events, several documents and interviews were examined. Interviews were carried out with local and central government officers; business elite members; community leaders, as well as consultants that participated in the coalition. Each actor was chosen by its role in the process, and an ad-hoc set of questions were designed to reveal specific information as well as to revise relevant events. Internal documentation of the municipality and Codesup was revised, as well as external sources of information, such as local and national newspapers. After comparing each source of information, a selected string of events has been chosen to explain the evolution of the coalition. In the whole, this research represents a highly resumed amount of information, a selection that would not have been possible without a rigorous methodology.

Finally, considering the limited time to develop the research, this study case has not been examined through Social Network Analysis to undercover the network ties, which was used by Nancy Holman in the Portsmouth case (2007). Therefore, special attention has been given in the design of the interview protocols.

\section{Limits of the Research}

Several aspects can be identified as limits of this research. Firstly, most of the regime study cases are cities in themselves, whilst this case is a large commune that administratively belongs to a city. Nevertheless, considering the autonomy of this urban centre, it can be considered as an autonomous town. Secondly, Dowding considers (2001) that study cases of cities are usually explanations of phenomenon that place much attention to local factors, while comparative approaches place an accent in generalizations. Therefore, it is relevant to point out that external factors are considered fundamental in this research because, as seen in this case, local and global scales constantly interact, as well as leaving the case open ended for comparative purposes. Thirdly, some of the prioritized economic policies are a common aspect between Johnny Carrasco's successive governments and the ones during the military government. Moreover, for Regime Theory the formation and evolution of a coalition is a fundamental aspect to outcomes, therefore these 26 years are relevant to explain eventual outcomes.

\section{CONTEXTUALIZING PUDAHUEL'S REGIME}

\section{Exogenous and Endogenous Forces}

In this section, relevant endogenous and exogenous factors regarding Pudahuel are exposed to give an initial understanding of the case's context. Pudahuel is a commune within the Valley of Santiago, capital of Chile. It has always been predominantly a natural and agricultural environment, with a small-town centre surrounded by rural roads. Nevertheless, in its recent history, new urban trends have substantially fragmented its traditional form of life (Naranjo, 2006). According to Geocities (2004), under the profound economic and political restructuring of the country in 1979, new urban policies, in one of the most orthodox versions of neo-liberalism, redefined Santiago's planning and urban strategies. The former green belt of the city became a fertile plain for urban development where public institutions were prohibited from interfering with land and housing markets. Pudahuel, which had the green belt crossing it, was directly affected by the new urban model. Additionally, housing policies moved poorer families from high income communes to 
the southwest sides of Santiago; many were moved into an area in Pudahuel known afterwards as Pudahuel Sur. Additionally, in the 1980 s, new environmental policies obliged many industries to reallocate to the outskirts of the city, and with an extensive network of highways, Pudahuel became highly attractive for this infrastructure. These national policies based on low regulation and restriction of the participation of local actors in planning initiated the social, environmental, and economic conflicts that Pudahuel suffers today. It also shows how welfare policies were subordinated to a more flexible development, giving importance to supply-side projects, which enhanced the city's economic activity (Harding, 1997).

After the dictatorship, a new left-sided local government took power in Pudahuel in 1992. Johnny Carrasco, having won with only an $11.2 \%$ of popular support, managed to be declared as Mayor, but his

new government rested on a small base of legitimacy, which would eventually encourage the set of participative programs to come.

The new government identified five relevant and conflicting areas in Pudahuel. The first one is the flooding area. Due to the valley's natural depression, overground and underground rivers concentrate in Pudahuel, over the extensive areas of Pumicite mineral (which makes the ground impermeable), creating severe cases of floods during rainy seasons. The second area surrounds the river Mapocho. Low environmental regulations allow industries from eleven communes to evacuate their liquid wastes into rivers, affecting Pudahuel's natural habitat, and eliminating the popular custom of using water sheds as swimming pools (called 'Pozones'). The third area is the international Airport. It is the only international airport in Chile, and its land use regulations have a belt effect on the commune's urban development. As local actors acknowledge, just having the airport, a national highway and a metropolitan highway attracts resources and economic opportunities which profoundly enhances Pudahuel's economic potential. The fourth area is Ciudad de los Valles area. It represents the new social reality of the commune, where middle class communities are becoming a relevant part of Pudahuel. The fifth area is what the Town centre of Pudahuel was initially. In the 60s it was divided into Pudahuel Sur and Pudahuel Norte by a highway that connected to Valparaiso. Pudahuel Sur, where most of the low-income families lived, was left out of the developing side of town and spatially segregated from the city. Until now, the urban development in Pudahuel is not the outcome of planning, and instead reflects the sum of individual actions in the territory. The situation demonstrates a need for leadership and agreement between the relevant actors, to manage the high level of environmental conflicts.

In 1994, new modifications in the PRMS ${ }^{3}$ added another layer of pressure to the existing problems in Pudahuel. Before the expiry of the old PRMS took place, dozens of project applications were received and approved by the local government. But to the dismay of local government and business elite, central government introduced an urban limit that left most of the projects outside the urban area. It also meant leaving $12 \%$ of Pudahuel as an urban area, and the resulting $88 \%$ to agricultural and natural use, however a considerable part of the agricultural area is unproductive. This intergovernmental contradiction would initiate the mobilization of local actors, and the start of Pudahuel's coalition.

In conclusion, before the coalition formed, the local government of Pudahuel showed little bargaining capacity (Kantor \& Savitch, 2005). With little legitimacy, and in a commune where development is mainly in the hands of business elite, the local government is in a position of dependency on private resources to accomplish their commitments (Davies, 2005), and is open to economically oriented local policies as well as having a disposition to negotiate. This position also explains the conditions under which the local government began to actively promote market-oriented policies. (John 1997; Harding, 1997).

\section{Chronology of Events}

This subsection focuses on the events and facts that, chronologically, demonstrate the birth, evolution, and conclusion of the Comisión Mixta de Urbanismo (from now on CM) of Pudahuel. The changes in the 1994 PRMS left numerous investors with an uncertain future for their investments (See Figure 1). Without central government's support for their projects, the business elite sought the local government's empathy. The first step to initiate conversations with the local government was taken by the business elite ${ }^{4}$. An important architect in the private sector with contacts in the local government convinced the business elite to form a group and arranged a first meeting with the Mayor of Pudahuel ${ }^{5}$. Even though most of the projects 
were outside urban limits, the business elite expected to have their applications approved through the traditional "ruta 6"6. This meant using the complex LGUC legislation to manage a change in land use and convert it into urban land. This unplanned form of development is one of the recent trends by which sprawl takes place in Santiago. This generalized practice created enormous revenues due to the change in land value. This first approach reveals the climate of informality and interdependency between the public and private sector, where little institutional intervention and intermediation made personal contact a relevant aspect for negotiations.

The municipality's initial position was against to approve such projects due to their negative impacts on an already conflicted social and environmental commune. Nevertheless, they were in an unfavorable position for negotiations because they had already approved a large amount of project applications (Sur Profesionales, 2010). Although they still lacked a clear view of what the commune ought to become, meetings continued with the business elite (Sur Profesionales, 2010). This type of public and private closeness has been used in other communes in Santiago to creatively shape projects, using informality and negotiation to achieve agreed objectives. This shows the efforts of Pudahuel municipality towards a coalition bonded by local concerns and actors, which has proved in other cases, such as Portsmouth or Atlanta, to be highly influential.

In 1995 Hidronor, a large firm implementing a sewage treatment plant in Pudahuel, received approval by central government to edify its project (Sur Profesionales, 2010). Central government localized the treatment plan through the PRMS, and without any compensation, designated Pudahuel as the adequate place for this infrastructure ${ }^{7}$. The community reacted strongly against this project, a NIMBY protest, arguing the lack of any security measures to protect communities from an environmentally hazardous infrastructure (Sur Profesionales, 2010). Nevertheless, as Burbank (2000) mentions: in front of strong public-private partnership communities have little influence in how the externalities are distributed. Eventually, the local government would receive the critics for not taking a stand in the situation. Nonetheless, this reaction provides evidence of local dynamic actors within the communities.

\section{FIGURE 1 \\ PUDAHUEL COMMUNE}

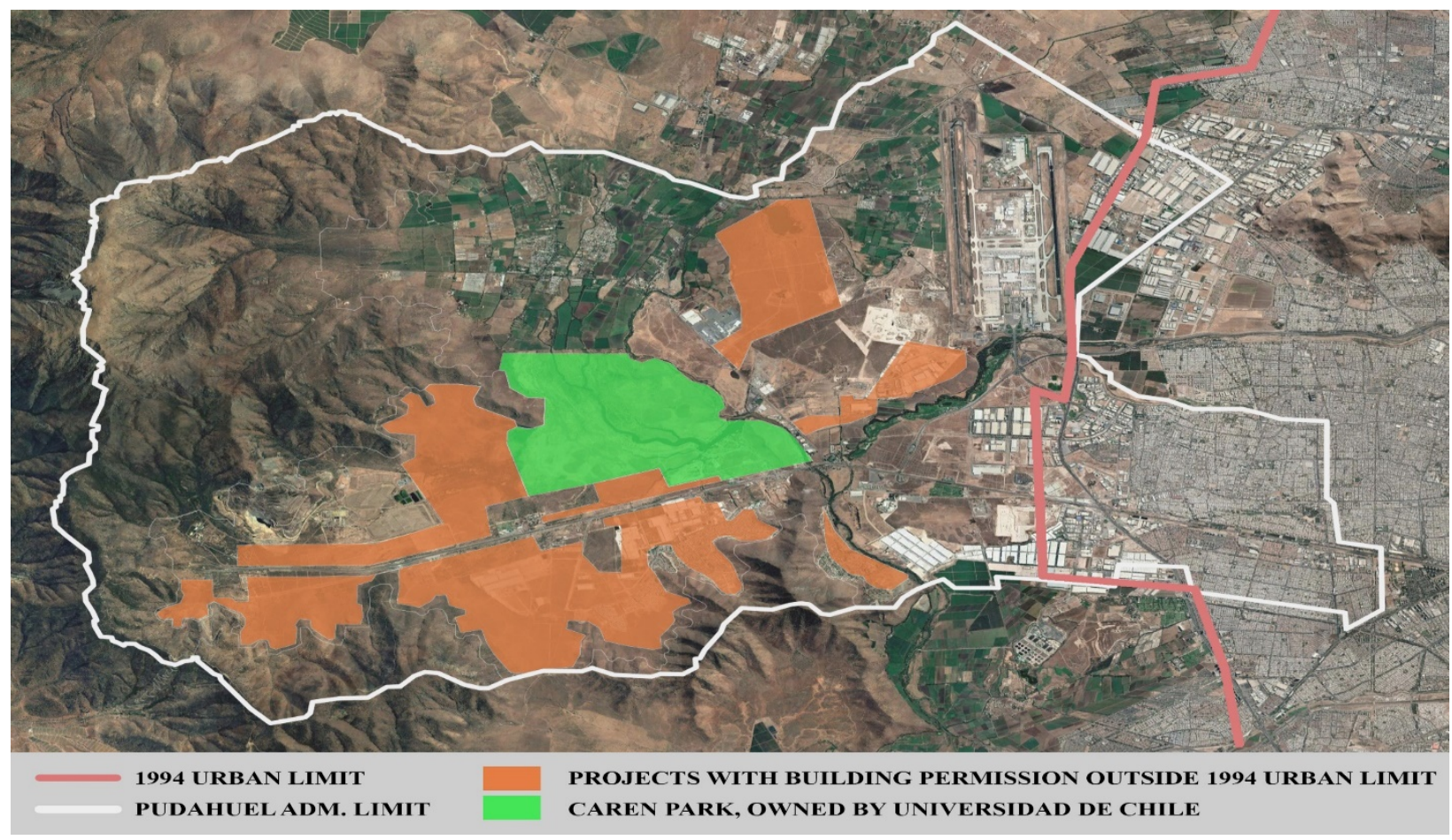

Source: Produced by authors

136 Journal of Leadership Accountability, and Ethics Vol. 18(5) 2021 
The local government was being pressured to act by groups coming from the business and community sector. In September 1995 the mayor called for an internal meeting between the key local public officers to discuss their situation (ACM, 1999). They evaluated two options for Pudahuel's future. One option was to allow and approve the projects and allow another Pudahuel Sur. The other option was to avoid such an outcome and try to manage the rising environmental conflicts (Sur Profesionales, 2010). Finally, the second choice was agreed: the most effective action was to elaborate a new communal master plan that favored an adjustment of the PRMS to the real conditions of the local territory (ACM, 1999).

Until now interdependence and a need to forge cooperation between the local government, business elite and local communities are displayed. Dynamic actors from business and community sectors recognize the unique attributes of their locality, and act upon them (Holman, 2007), signaling the local government to participate as relevant actor. Therefore, these events are recognition of interdependence.

By November 1995, the mayor announced the creation of the CM (ACM, 1999). The local government quickly found Article no. 49 of the LGUC (Marin, 2000; Bresciani \& Marín, 2000; ACM, 1999) which allowed them to create a new local master plan (which they were obliged to do anyway) through a wider public and private participation. The law gave a legal umbrella for local leaders to act and carry on with informal arrangements without institutional intervention from central government. Public officers must form part of the process of prioritizing interests between the participating sectors and define the guidelines for the Plan Regulador Comunal (From now on PRC). The CM had to be voluntary and ad-honorem, which allowed the process to be privately financed. According to Luis Marin, this law has not been used before to solve a commune's strategies, therefore using it is an innovation in planning (Marin, 2000). Article no. 49 represents what Schuster (1995) would recommend: stimulating active communities to embed projects into their customs: a legislation encouraging local actors to initiate participation around inclusive activities that benefit the place.

As negotiations continued, business access to knowledge and skills began to overweigh local government's capacity to lead the process (Sur Profesionales, 2010). The municipality's lack of a common objective and coordination began to weaken the process. While the local government requested that the business elite reshape their projects, in turn they were asked for efficiency. This meant coordinating the actions between the departments and having one clear position. Johnny Carrasco sought support from all departments and encouraged them to overcome their ideological mistrusts that worried the opposing public officers. These public officers asked for guarantees, which were agreed in the following arrangements. Firstly, the roles of both parts had to be more specified. Secondly, one technician or professional from each department must participate by forming part of a new Technical Commission (ACM, 1999). Additionally, the Comision Urbana Municipal ${ }^{8}$ was created to introduce the municipal strategies into the negotiation process (Sur Profesionales, 2010). According to Luis Marin, achieving success in the process was done by managing consensus between the different professionals, departments, and technical groups ${ }^{9}$. This meant coordinating in a large institution, which is an objective that is not always successful. In Stone's (2001) terms, these internal arrangements represent issue framing that "... not only highlights broad purposes and gives them appeal, but [it] can also identify specific roles to be plaved and can also show how these roles fit together" (p.23)

The PRC negotiations took a further inclusive and informal pattern within the municipality. Not after long the creation of a new CM was heard by some social leaders that worked in the municipality, who pressed for participation in the CM (Sur Profesionales, 2010). And in 1996 the CM invited the main leaders from the Union Comunal de Juntas de Vecinos ${ }^{10}$ into the negotiation process. The result was having an active daily and weekly visit of community leaders in the municipality which became part of the common "landscape" (Sur Profesionales, 2010). Even though the coalition grew, the informal and collaborative arrangements continued, where knowledge spill-over linked community problems to the decision-making table, where issue framing was taking place.

Not long after, the Consejo Economico Social Comunal (Cesco) was included in the process. Nevertheless, it was noticed that the community leaders lacked the understanding and specific knowledge to contribute to the negotiation process (Sur Profesionales, 2010). For this reason, by June 1996, an agreement to organize ECO was made: Primera Escuela de Capacitacion para Lideres ${ }^{11}$ was formed of forty 
community leaders in community development, planning aspects, environment issues and the role of civil society (ACM, 1999). This initiated a transfer of business resources around a set of socio-economic policies that, according to a community leader, helped the understanding and spread the knowledge about contemporary urban processes throughout Pudahue ${ }^{12}$. The initiative of sharing information is also a fundamental principle in urban economy, allowing markets to function more efficiently and transparently.

Until now the local government had expanded the number of participants in the coalition, adapting its arrangements to maintain its informal and collaborative character. As a reaction to the demands of the private sector, a new form of cooperation within the municipality produced efficiency and coherence, which would not have been attained without cooperation. The result was a reorganization of the initial coalition, where new networks were included, and arrangements adapted to maintain diversity of informal channels to the negotiating table (Holman, 2007).

The business elite began to regularly finance the coalition's activities. By July 1996 the JUNDEP had organized six new seminars in which 600 leaders and prospective social leaders participated (ACM, 1999) The central idea of the seminars, which was compensation, would become the common purpose of Pudahuel's process: if urban development is supported, it cannot conclude in another socially deprived area, or the disappearance of the rural and natural attributes of Pudahuel. As Marin mentions, the process must consider the existing Pudahuel Sur, providing the options to enjoy diversity, to access health, education, work, green space, culture art, leisure, sports and security, and "its natural and agricultural heritage (Bresciani \& Marin, 2000). Additionally, the municipality received professional consultancy, such as MECSA $^{13}$, for the PRC development (ACM, 1999). The Oficina de Planificacion Urbana was created, which included new professionals and equipment where USD 220,000 was investment. After the new community protests against central government's plans to implement the water treatment plant and a large domestic gas station in Pudahuel, antagonism against the local government rose again. To avoid splitting the community from the coalition, business resources were once again mobilized and a new Escuela Comunal de Urnanismo initiated (ACM, 1999). The topic was territorial planning and municipal management, and approximately one hundred people from the local community assisted. As a former consultant ${ }^{14}$ of the CM mentioned, the need for transparency is a fundamental aspect of maintaining the process under control. As Stone (2005) mentions, the impacts of the government's policy depend on complementary action from non-governmental sources, therefore "achieving an accommodation with those who control the levels of economic activity" (p.311) will help them achieve their commitments, being one of them participation. Therefore, creating a network between community and private sector through the municipality is part of this accommodation.

At this point it was decided that marginalizing the central government from the table was not congruent with the idea of changing the PRMS ${ }^{15}$. The municipality initiated through political linkages, cooperation with specific public officers from the ministry of Transport ${ }^{16}$. The political support and transfer of resources (consultancy, transport, and infrastructure design) increased the competitiveness of Pudahuel, as well as its control over its local assets. This specific ministry helped to increase the "pulling-in effect" (Stone, 2001) of the coalition. By pressuring Real Estate Companies to go along with and adapt their projects to the new PRC's housing standards policies.

In March 1998, due to a drawback in the municipality-business relationship the coalition was restructured once again. The municipality finished the contract with MECSA, the consultants that carried out the PRC (Sur Profesionales, 2010). The argument was that they were representing solely the business interests. The discussion centered on who decided how land was to be used: the business elite defended their inherent right to develop their resources, and the municipality answered that development must not replicate existing deprived areas. To reestablish relations, the business sector offered more planning autonomy for the local government ${ }^{17}$. This meant building a separate department with equipment, professionals, and the latest computer programs for the PRC planning tasks (Sur Profesionales, 2010, p.6). The local officers would be responsible for concluding the planning process. The generalized unwillingness of local public officials to work overtime for the PRC helped to internally separate the PRC group from the rest of the municipality. The business elite financed the salaries, but accountability was taken care by the municipality's finance department. An internal commission would evaluate the congruence of the programs 
and its finances. The impact of trusts on public-private relations has now become a relevant factor for cohesiveness. It mobilizes resources and even modifies the power structure, form of collaboration, as well as taking one more step towards autonomy. Additionally, committing to cooperation has high costs; it requires constant financing and limits the actor's independence of action (Stone, 1989).

In 1998, a brief intervention of a central government official introduced a new urban model that became the solution for Pudahuel's compensation issue. The model, named PDUC ${ }^{18}$, not only meant physically modifying the projects. It also intended to make business sector responsible for the costs of development ${ }^{19}$, which solved the problem of who bore this cost in Pudahuel. This allowed finalizing the PRC by year 2000. As the ACM document $(1999$, p.5) states:

"... once achieved the PRC project through a consensus... the coalition favors the establishment of a model of cooperation that brings two relevant aspects into one framework: social development and local economic development. From this point on, the need to institutionalize the agreements should be achieved through the creation of a new development agent, an agent that takes a form of a corporation."

This statement demonstrated the need to continue the coalition in a more autonomous form. By year 2002, Codesup or Corporación para el Desarrollo Sustentable de Pudahuel (ACM, 1999) was created. It is a non-profit corporation financed by the business elite, and it gave the informal arrangements of the coalition the independence that its participants required. According to Bresciani ${ }^{20}$, Codesup represents the continuity of the coalition.

Finally, within each of the selected events more than one of the ten points has been identified. Additionally, the evolution of all the events shows how trust and agreement was built; consequently, all of them are relevant to appreciate these two essential Regime characteristics. This would lead to the understanding that Regime characteristics, as mentioned by Stone (2001) are fundamentally interrelated. Other points that repeatedly appear throughout the case are setting arrangements, dynamic actors, and cooperation. The analysis also reveals that many of the conflicts between public officers were caused by the fact that they were being financed by the business elite and the implications this meant in becoming more permeable for economic oriented policies. However, the local governments support for the business elite shows a clear shift of the local government to an active agent promoting productive policies (Harding, 1997), where not only does it support entrepreneurial activities, but it also becomes one through its creative contributions to solutions. This internal conflict is also evident when the PRC group had to move their working area, initially within an institutionalized structure, to the more independent office that it now has: a corporation composed of public and business representatives working on the administrative floor of the Airport. What is particularly evident is the open intention of the coalition to guide local development, a decision to work together that was not induced deliberately by central government, signaling weaknesses in the capacity to control urban economy without local actor's aid (John, 2001; Viesti, 2002).

\section{Impacts of the Coalition}

In this subsection the coalition is examined in terms of its main impacts between 1994 and 2010. Submitting the PRC meant that one of the main priorities of the common goals had been completed. Nevertheless, the promise to respect the agreements and implement the PRC is still the common purpose that gives sense to the coalition. Although some problems have been identified, the coalition still proves capable of mobilizing resources and power, establishing continuity and autonomy of the process.

With the PDUC model, the business elite had two outcomes with their projects: some received the central government's approval to build, but other did not $^{21}$. However, Bresciani ${ }^{22}$ recognizes that Pudahuel's process became an opportunity to redesign the PDUC:

"Evidently the creation of norms for PDUC in 2002 and their approval reduced (local actors') tensions (in Pudahuel) ... Although most of them (PDUC norms) were not thought 


\section{for Pudahuel...the Pudahuel experience and other peripheral communes were very helpful in its design."}

Paradoxically, the business elite funded a process that became useful to redesign the newest tools to control urban development in Chile ${ }^{23}$, achieving a positive outcome for the city (Holman, 2007). Additionally, the business elite's outcome shows how sensitive centralized planning is to lobbying systems, favoring some firms more than others ${ }^{24}$. Although the case of Pudahuel still supports the idea of a change from government to governance (John, 2001), it also clarifies the significance of lobbying in the permeability (Kantor \& Savitch, 2005) of local decision making and as a factor that explains the shape of cities.

On a local scale, the coalition managed to implement their own policies, which raised the quality of life comparatively higher than other low-income communes. The policies affected housing standards and adapted public infrastructure according to unique features of the locality, such as flooding and rain evacuations. The coalition also engaged in creative solutions for those projects that stagnated due to the more restrictive PRC policies. The Enea project, which in its initial design would have created social and environmental conflicts, received specific land use solutions to avoid such outcomes. Additionally, job programs were implemented to reduce joblessness in the commune. Coalition actors convinced different local businesses to hire a minimum of local workers onto their staff to increment local employment ${ }^{25}$. Eventually, firms adopted the habit of advertising their job placements through the municipality, a system that is still in use today ${ }^{26}$. In conclusion, the coalition became an instance of shaping a project according to the relevant issues affecting the commune and agreed common purpose and achieving outcomes that otherwise would not have been possible.

Financing the coalition's activities required efficient decision making, a necessity that derived from assigning someone to handle funds quickly. A public officer was eventually elected to administer a bank account opened by the business leaders, where a simple phone call quickly assigned funds for small programs $^{27}$. This level of trust between public and private actors is due to the experience and legitimacy gained from the process and years of collaboration, a system that still characterizes Codesup today.

According to Luis Marin, the compensated growth concept is the CM's main legacy, and refers to how externalities are unevenly distributed in Santiago. The CM's central issues are rooted in two patterns of urbanization. The first pattern is how private entrepreneurship is allowed to develop the city without having to assume the responsibilities of the externalities ${ }^{28}$. The second pattern is the powerful partnerships between the central government and large private firms that localize their projects without properly taking into account social and environmental consequences ${ }^{29}$. From this perspective, Pudahuel's CM resembles Burbank's (2000) anti-growth movements against the coordinated action of state-business partnerships. Nevertheless, it has two differences. Firstly, it seeks to select and control local social production (Harding, 1997). This attitude is mainly caused by the prevailing business' intention to protect the value of their assets through the coalition (John, 2001). Secondly, as a cooperative regime, their legitimacy, power and resources are higher than Burbank's cases, so offering an alternative scenario is possible, and their effort can be sustained in the long term.

After the CM dissolved, most of the relevant actors continued working together through Codesup ${ }^{30}$. They included educational and heritage concerns as priorities in their agenda. The consensus that Pudahuel is fundamental for the economic expansion of Santiago has strategically prioritized areas for local economic growth demonstrating as well the "fusion between local government and markets in a highly competitive market economy" (John, 2001). After years mobilizing resources for the PRC policies, strategies to maintain the commune's attractiveness emerged. Codesup eventually engaged in changing the face of a marginalized commune to a sustainable place for living ${ }^{31}$. Promoting the socially-responsible-companies concept successfully attracted new firms into the coalition, and educational programs about compensation in planning served to expose the coalition's achievements. Codesup was a consequence of the coalition's evolution, and still affects planning in Pudahuel. Other weaknesses in the process can also be identified, which may eventually affect the regime's cohesiveness. Firstly, urban development pressures to use areas that still have large rural communities. The persistent resistance of these communities to participate 
in heritage policies that protect their lifestyle may set the stage to marginal: them from any compensation of urban development ${ }^{32}$. Secondly, local government cohesiveness may become once again conflicted if challenging issues reappear in Pudahuel. Thirdly, although agreements have had a staying power (Stone, 1989) negotiations were led by strong leaders, and their eventual substitution may change the creative behavior (John, 2001; Harding, 1997) of the coalition, and consequently the social/market orientation of policy (Kantor \& Savitch, 2005) These factors may weaken issue framing and set the stage for regime decay (Stone, 2001), the most significant example being institutional cohesiveness.

In general, the impacts confirm that Pudahuel's outcomes would not be possible without a collaborative coalition. Although the business elite's outcomes were divergent, the coalition defined an agenda and implemented a set of concrete programs through a coherent common purpose that responded to local needs. Although the outcomes of the projects reveal central government's capacity to circumscribe local decision making, it was the coalition's legitimacy and cooperative form that justified using and modifying the PDUC model. The stable flow of resources that sustains in time the creative programs (John, 2001), and keeps the process' adaptive response assisting and managing conflicts (John 2001) means that it cannot be considered as a case of Burbank's (2000) unpowered coalitions. Codesup is relevant today because it contains the engagement capacity of relevant actors, keeps the task of linking relevant issues to programs, and sustains the coalition's effectiveness in problem-solving (Stone, 2001). In conclusion, the coalition has a staying capacity (Stone, 2001) and effectiveness that still shadows the identified weaknesses. Nevertheless, more time is needed to fully evaluate if they weaken the coalition. For now, the coalition is not considered weak.

\section{Findings}

In this subsection the objective is to evaluate how well the ten points can be identified in the study case. Each of the ten points is discussed in a paragraph, according to the events and facts gathered previously, to highlight as clearly as possible the "less visible aspects of governing arrangements at the local level" (Holman, 2007). There are five characteristics that make up the set of arrangements through which a community is governed (Stone, 2001). Firstly, there is an identifying agenda. Secondly, the arrangements have stability, and in Pudahuel's case Codesup is responsible for maintaining the active network. Thirdly, the arrangements have a cross sector foundation (Stone, 2001): Codesup, a non-profit organization run by public and private actors that updates their agenda and carries the task of framing purposes, linking them to resources and implement programs (Stone, 2005). Fourthly, arrangements are informal, a characteristic running across the whole process, and present in Codesup that has no power command directing the overall arrangements. Instead, it relies heavily on cooperation. Fifthly, the arrangements have a productive character, and today Codesup still runs a constant flow of programs that maintains the framing process and active networks. This also demonstrates that there is a stable base for cooperation. As a conclusion, although different firms and actors have changed in time, the form of problem solving carries on. This point is considered identifiable.

The common purpose, which is development with compensation, is recognized through existing research documents, relevant actors' interviews, and demonstrates the course of action mentioned in the contextualization section. Codesup's mission statement reveals this purpose: "to solve the economic and social problems of Pudahuel that arise from development through public and private cooperation" 33 . The ACM document (1999) also specifies the accomplished broad purpose (Stone, 2001) of the coalition: achieve public participation in all processes; autonomy for the coalition; higher level and a social and economic cohesiveness; create a diversity of compensating mechanisms and guarantee that businesses contribute to these mechanisms and solutions. The coalition programs tend to ensure the economic growth, revealing the cohesiveness and key role of the business elite in the Regime (John, 2001). Nevertheless, the unexpected demand to establish a new form of collaboration stressed relation between departments groups and officials. Although the Mayor finally aligned the diverging criteria and assured the necessary transformations that kept its strong institutional presence (Stone, 2001), the local government's size and diversity finally affected using more effectively the common purpose.

Holman refers to John's (2001) concept of the uniqueness of a locality, or to the conditions that make it possible for regimes to emerge from them. In Pudahuel's case, several key exogenous and endogenous 
factors can be identified. The exogenous factors are the effects of the deregulated planning of PRMS, and the placement of large urban projects without considering its social and environmental effects. Both allow large entrepreneurial freedom for developing the city without compensating the negative externalities of the process, Pudahuel being particularly affected by these factors. The exogenous factors pressured local actors to mobilize towards action. Three local sectors reacted to these pressures and sought collaboration. Pudahuel's business elite looked for the local government's support to find a solution to their stranded projects. Their common interest and comparatively higher access to resources and skills kept negotiations in their favor during most of the process. The public sector found the business elite's willingness to negotiate as a chance introduce social reforms to their projects. Initially the communities were not included. Once business and public elites formed a steady coalition, then the municipality engaged communities through local leaders and the educational programs. These three sectors eventually managed a level of cooperation that overcame mistrust and readjusted the centralized form of planning imposed over them.

However, some limits to the actors' capacities to act can be identified. The first one is in solving environmental pollution. Pudahuel's waterways are contaminated. A solution is dependent on the water management and city design. And this requires an intervention from a higher government tier to coordinate a change. The second limit is the reduced political will to create conservation policies that keep local rural and natural attributes. Decreasing land used for development means moving away from the coalition's business-oriented programs. Thirdly, Pudahuel Sur is sensed as an issue that the coalition is not entirely prepared to solve. It has a high level of spatial segregation, therefore improving connectivity and public infrastructure is as far as the coalition's policies go. In conclusion, local actors act and recognize local attributes, but when solving environmental issues, the coalition's economic orientation tends to keep the costliest environmental policies as secondary objectives.

The coalition attracted resources and capital through different initiatives. Physically speaking, its main comparative advantage is the combination of large quantities of cheap land and the highway infrastructure that keeps these areas well connected to the rest of the valley. Nevertheless, the Diputacion de Caceres, from Spain, funded the coalition's Compensation model because the coalition guaranteed a "...political capability to use bargaining resources" (Kantor \& Savitch, 2005), that assured a decent level of governance over urban development. Additionally, having the only international airport of Chile boosts economic activities not only within Pudahuel, but also in other communes, making it nationally strategic for mobile capital and labour. Pudahuel's social and environmental conflicts initially scared business initiatives, but with a coordinated management of local assets and a coherent set of socio-economic policies the face of Pudahuel as a deprived area changed substantially. The knowledge built through the coalition process and its visible results became a marketing tool to keep investments flowing into the commune. Much of the new investment came through higher demands on private firms (Kantor \& Savitch, 2005). PRC policies made projects in Pudahuel generally more expensive by raising land prices and affecting local assets by surrounding them with rising value areas. It must be mentioned that there are many of the business elite's initial projects that still encounter resistance from different government tiers. Although there are market conditions to support urban growth, the intergovernmental mechanisms (Kantor \& Savitch, 2005) left these projects caught in Santiago's master plan transition. Economically, this meant midterm costs for Pudahuel because it reduced several investments coming from large projects. But socially, it meant long-running benefits through the regulation over the types of projects that are allowed to attract mobile capital and resources.

The strong pressures on deprived areas, where collaborative forms of governance seem to be the obvious solution, have not always initiated coalitions (Stone 2001). The autonomous cross-sector collaboration, with a strong leadership and clear common purpose made long term planning and deep restructuring a reachable goal (Stone, 2001). Regimes require an enormous amount of time, effort and economic investment and once collaboration is in an advanced level of agreements, getting off the tracks has more costs than staying on (Stone, 1989). Although more time needs to pass to evaluate how consistent are the coalition's impacts, the stable public-private foundation has responded efficiently and inclusively to the pressures of development. In this sense, the nature of the collaboration has problem solving power, which is highly relevant if the coalition is to be evaluated as strong. 
Urban Regime literature commonly mentions cases where trusts existed prior to regime formation, but in Pudahuel this not the case. Trusts were formed in a few years, under pressure and through diplomacy, overcoming ideological differences. On occasions there were drawbacks, reflecting negotiations of individual preferences (Holman, 2007). Trusts were also created within each of the sector's network, where the communities, local authority and business elite internally persuaded their group to take a specific stand. What brought actors to the table was that each sector actively demanded to be part of the solution, where interdependency kept a listening attitude. Two arrangements were particularly relevant to building trust within and between networks. One factor was the commitment that each negotiated agreement would be respected and supported by all. The other was maintaining accountability throughout the whole process.

As the CM actively sought the creation of the PRC, resources were shared sector to the other allowing inclusion and efficiency in the process. The private sector financed the access for local leaders and communities to relevant information necessary for the participative process. Without this aid, the PRC would not have been efficiently delivered to the central government. On the other hand, local government's skills and knowledge quickly identified article no. 49 of the LGUC, inspiring ad-hoc financial and legal arrangements to guarantee participation and transparency. In turn, the community has supported the results of the coalition by reelecting Johnny Carrasco five times as Mayor. They legitimize the process and allow the PRC team to continue leading. These resources mobilized by the three sectors have allowed the coalition's framing system (Stone, 2001) to function affectively and informally. Therefore, the mobilized resources have strengthened the participative and productive nature of the arrangements.

The three sectors used their networks to reinforce the coalition's arrangements and increase their bargaining power (Kantor \& Savitch, 2005). Local government, for example, attracted the support of planning agencies such as SOFOFA, Fundación Lo Aguirre, and the Ministerio de Obras Públicas. Community leaders engaged local organizations and whole neighborhoods to participate. The business elite brought highly skilled agencies to support the planning tasks of the PRC. Usually, the business sector has a clear, competitive, and pragmatic vision that bonds them strongly. Until today, no conflicts within the business elite have been mentioned, making them the most cohesive group of the coalition. Through the community leaders and public officers, the business elite accessed other agencies, which extended their influence over other areas of Pudahuel. Additionally, control over program funds assured that their interests were most of the time fully integrated in the coalition's actions. Although the coalition transcended inside and outside Pudahuel, the contrasting outcomes of the projects showed how permeable (Kantor \& Savitch, 2005) localities are to external pressures. Today, in less conflicting circumstances, a reduced number of agencies are used, although the diversity of firms representing the coalition today has increased. This point is also identified but is weaker than most of them.

Using Article no. 49 meant creating an inclusive structure to formulate a PRC, where public officers participated on behalf of the municipality. Four stages can be identified to account for the evolution towards an autonomous coalition. The first one is when municipal dependencies were used to establish informal relations with the business elite. It is characterized by the municipality's difficulty to efficiently respond to an overwhelming private sector that led decision making in the PRC. The second stage began with a transfer of business resources to improve municipal infrastructure and involve consultancy. Although efficient delivery was achieved, it also accentuated differences between the PRC group and the rest of the municipal staff, who questioned the business elite's high level of involvement in activities traditionally carried out by the local government. In the third phase, after having acquired legitimacy with communities, the PRC group became spatially and financially divorced from the municipal departments. The fourth phase, Codesup was created. The corporation, through its networks, managed to acquire office space in the airport's administrative floor, where it develops its activities today. As the institution amassed power and learnt from the process, their level of cooperation increased, requiring a change of cooperative structure. This institutional transformation demonstrated the level of human and social capital achieved in the coalition.

Stone (1989) considers the selective incentive principle as the capacity to attract other civic entities into the governing coalition. He describes this principle as an effective form of discipline, also expressed through the idea of "going along to get along". In this sense, one factor that maintained the discipline of the coalition was the commitment to respect all the agreements achieved during the negotiations. As Luis Marin 
mentions, this was the hardest thing to achieve. No developer, inside or outside the coalition, was lawfully obliged to take them into account. Nevertheless, respecting the PRC had the benefit of acquiring a better reputation, and accessing an elite network of private firm contacts through Codesup. Another factor was the coalition's gravitational pull ${ }^{34}$, capable of shaping the private projects according to Pudahuel's new policies (Stone, 1989). This attitude of going along (Stone, 2001) with the regime, or willingness of the actors to accept "something more altruistic... as an incentive by those who hold the power" (Holman, 2007) can be identified in both factors.

Finally, several regime concepts can be highlighted from this analysis which reveal some unique features of this study case. (1) Public -private cooperation was not initiated by any formal program, or by central government's initiative. It began informally, characterized by interdependence and cooperation. (2) The concept of development with compensation became the coalition's common purpose which was legitimized after extensive community participation programs. (3) Each sector not only sought support within their groups for the welfare of the coalition, but also brought in a diversity of agencies and complementary resources which in turn increased their negotiating powers. (4) The CM's policies sought redistributive and economic policies to balance urban development through a stable public-private foundation that coherently responded to the disintegrative pattern of urban development in Santiago. (6) To establish trust, bonding agreements and pulling in capacity (Stone, 1989) were created, forming a wide range of public and private networks which assured that decision making had impacts in Pudahuel. Today, the coalition is visible through Codesup, which still maintains its initial informal and cooperative working form. Nevertheless, some points, such as the ones related to the common purpose, dynamic actors and attracting mobile capital have proved weaknesses. The first aspect refers to institutional cohesiveness and its effects over the use of a common purpose. The second aspect refers to the "permeability' (Kantor \& Savitch, 2005) of localities, or how higher tier governmental structures circumscribe a local actor's capacity to act. The third aspect refers to how some priorities tend to have more priority than others (Stone, 2001), and in this case how economic policies have more importance over social ones. In conclusion, the study case has not failed in any of these ten points where essential regimes characteristics are identified. However, specific weaknesses must be acknowledged to understand the strength of the coalition.

\section{CONCLUSIONS}

So, is there a recognizable regime in Pudahuel? When reviewing the ten points in findings, almost all have been well evaluated. Nevertheless, the approaches have also highlighted three weaknesses that should be considered for this case study. These refer to the "permeability' (Kantor \& Savitch, 2005) of local coalitions; how business centered coalitions shape types of implemented policies (John, 2001); and how institutional cohesiveness defines how the common purpose is achieved. The coalition is not 'hyperpluralist' (Dowding, 2001), where the strongest sector is the business elite, and the less powerful is the community. However, the coalition has been considered by the local communities as successful, and influenced by positively changing living conditions, and not just land value. The general conclusion is that, through the ten points, an urban regime is identified.

In terms of the impacts, the evidence indicates a strong coalition, capable of controlling and adapting in time to changing circumstances. The identified weaknesses are limits set by participation conflicts, internal cohesiveness, and how members' behavior affects policy creativity (John, 2001). This may eventually reduce the coalition's capacity to adapt to changing circumstances" (Stone, 2001). However, a defined agenda, concrete programs and coherent common purpose have prevailed in time. Additionally, as mentioned in the coalition's impacts subsection, relevant aspects such as the stable flow of resources and the adaptive response to Pudahuel's shifting conditions (John 2001), support the identification of a Regime. Although business sectors had divergent results, their funded programs transcended the new national urban policies. Nonetheless, more time may be required to fully evaluate the strength, how the Regime's issue concerns come to be specified as purposes, linked, and refined for action (Stone, 2001) enable it to be categorized as strong. 
Codesup was created to establish an autonomous foundation that kept alive the agreements of the PRC. The corporation's existence not only reveals a lasting public-private relation of the CM. It also inherited the responsibility of maintaining relevant actors engaged whilst keeping the task of linking relevant issues to programs, and sustain the coalition's effectiveness in problem-solving (Stone, 2001). With these circumstances and responsibilities in mind, it can be concluded that Codesup has relevance in decision making in Pudahuel, and still maintains the three fundamental Regime characteristics that have prevailed all throughout the public-private relation since 1994: trusts, informality, and cooperation.

Two factors were distinguished as externally imposed structures that predisposed local actors to specific behaviors that influence on urban development (Harding, 1997). Both sets of urban policies, imposed by central government, proved to be contradictive. They evidenced the difficulties of controlling urban growth and efficiently delivering policies without the participation of key actors and locally created knowledge (Viesti, 2002). This kind of political control over urban economy proves to be fragile (John, 2001) in places such as Pudahuel, where a Regime emerged to manage and reshape central government's development model. The creation of a new agency (the Regime); the shift from a formal pattern of planning; the local government's engagement in a highly competitive market economy; and building upon strong relations between local decision-makers to solve the central problem of planning are all characteristics that demonstrate the shift from government to governance (John, 2001).

Finally, Regime Theory still provides a useful framework through which key factors that shape local governance can be identified. Some patterns of local governance reacting to national and global pressures have been identified in other poor communes of Santiago valley ${ }^{35}$. But regime formation is more of an exception than a rule. And exceptional cases like Pudahuel suggest some forms of collaborations impact well beyond their administrative boundaries. Santiago has no Mayor or metropolitan government coordinating development. Therefore, it is hoped that this case study sheds light on key factors that local actors should consider when implementing socio economic initiatives related to distributional issues and social segregation.

\section{ENDNOTES}

1. $\quad$ Davies J. (2003) Journal of Urban Affairs, Volume 25, number3, pg 257

2. Holman, Nancy: "Following the signs: Applying Urban Regime Analysis to a UK case study" Journal of Urban Affairs (December 2007): 435-453.

3. PRMS means Plan Regulador Metropolitano de Santiago: it is the master plan of Santiago, and its surrounding areas within the Metropolitan Region

4. In this dissertation, Municipality and Local Government are used with same meaning.

5. Interview with Marin, L.: June 2010.

6. Term used to address a specific legislation in the national Planning normative document, L.G.U.C. to change land use.

7. Interview with Marin, L.: March, 2009

8. Formed by three department directors of the local government.

9. Interview with Marin, L.: March, 2009.

10. Union of Neighbors Association

11. First School for Local Leadership

12. interview with Torres, E.: August, 2010.

13. MECSA: an urban consultancy hired by the business sector to develop the PRC between the PRC between 1995 - 1998.

14. Interview with Echenique, M.: August, 2010.

15. Interview with Marin, L.: March, 2009

16. Interview with Marin, L.: June 2010

17. Interview with Echenique, M.: August 2010

18. Proyecto de Desarrollo Urbano Condicionado.

19. Interview with Bresciani, L.E. July 2010.

20. Interview with Bresciani, L.E. July 2010.

21. Interview with Fernandez, J.: August, 2010 


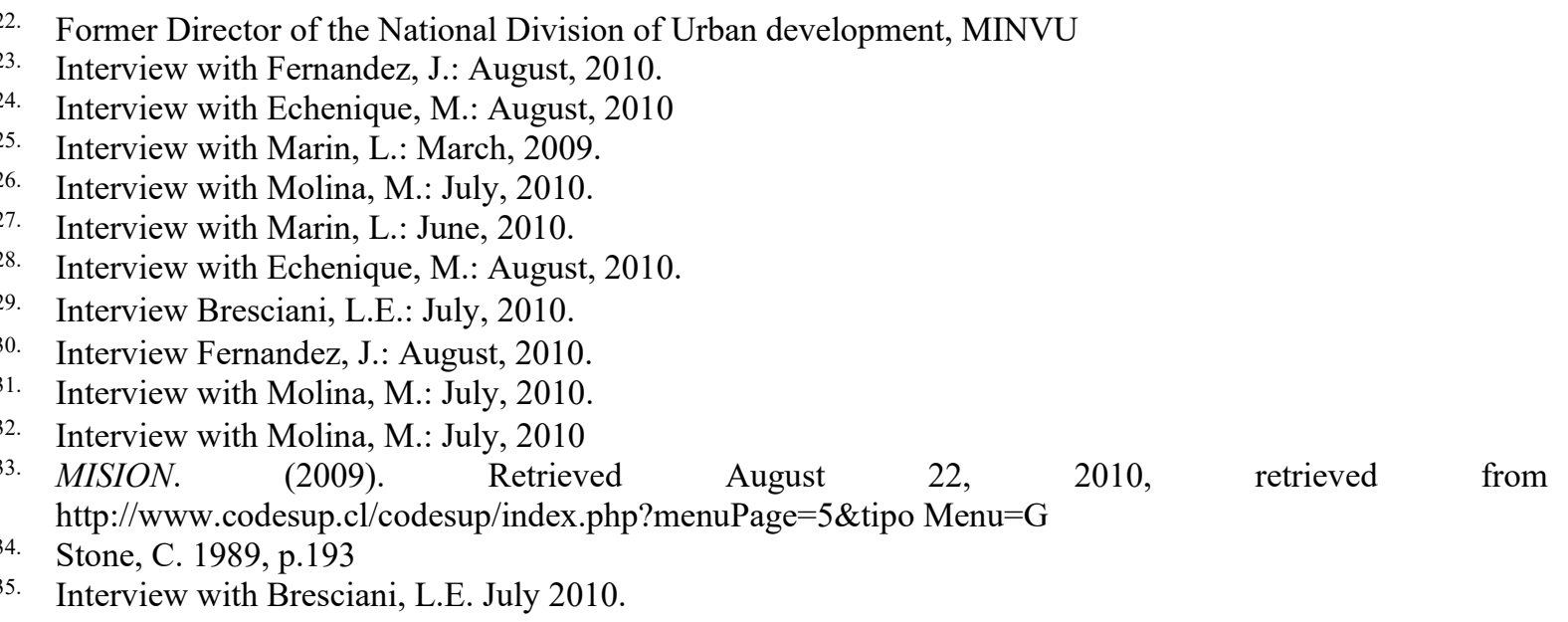

\section{REFERENCES}

ACM, Asociasion Chilena de Muncipalidades. (1999). Proyecto Plan Regulador ciudadano. Santiago, Chile: Asociación Chilena de Municipalidades.

Alvarez, E. (2010). La comuna de Pudahuel: Gestión territorial: Elaboración del Plan Regulador Comunal. Montevideo, Uruguay: International Development Research Centre.

Begg, D., Fischer, S. \& Dornbusch, R. (2008). Economics (9th Edition). Berkshire: McGraw-Hill Education.

Bresciani \& Marín. (2000). Sintesis Doctrinaria del Pensamiento de la Comisión Mixta de Urbanismo. Santiago, Chile: Ilustre Municipalidad de Pudahuel.

Burbank, M.J., Heying, C.H., \& Andranovich. G. (2000). Antigrowth Politics or Piecemeal Resistance?: Citizen Opposition to Olympic-Related Economic Growth. Urban Affairs Review, 35(3), 334357.

Comisión Redactora. (1995). Conclusiones Jornada de trabajo Plan regulador Comunal y Valle Lo Aguirre. Santiago, Chile: Ilustre Municipalidad de Pudahuel.

Creswell, J.W. (2009). Research design (3rd Edition). Thousand Oaks, California: Sage Publications.

Creswell, J.W. (2009). Research Design Qualitative, Quantitative and Mixed Method Approaches (3rd Edition). Thousand Oaks, California: Sage Publications.

Davies, J.S. (2003). Partnerships versus Regimes: Why Regime Theory cannot explain Urban Coalitions in the UK. Journal of Urban Affairs, 25(3), 253-269.

de Vaus, D. (2001). Research Design in Social research. London: Sage Publications.

Downing, K. (2001). Explaining Urban Regimes. International Journal of Urban and Regional Research, 25(1), 7-19.

Fainstein, S. (2001). The City Builders, Property Development in New York and London, 1980-2000 (2nd Edition). University Press of Kansas.

Geocities 2004 GEO Santiago. (2003). Perspectivas del Medio Ambiente Urbano. Santiago, Chile: PNUMA-Eurelibros.

Harding, A. (1997). Urban Regimes in European Cities? European Urban and Regional Studies, 4(4), 291-314.

Holman, N. (2007). Following the Signs: Applying Urban Regime Analysis to a UK case study. Journal of Urban Affairs, 29(5), 435-453.

IM. (1995). Two Urban Festivals: La Merce and First Night. Planning, Practice and Research, 10(2), $173-188$.

John, P. (2001). Local Governance in Western Europe. London: Sage Publications.

Judge, D., Stoker, G., \& Wolman, H. (1995). Theories in Urban Politics. London: Sage Publications. 
Kantor, P., \& Savitch, H.V. (2005). Debates and Developments. How to Study Comparative Urban Development Politics: A Research Note. International Journal of Urban and Regional Research, 29(1), 135-151.

Marin, L. (2000). Minuta, Pudahuel: Una Experiencia de Planificación Territorial Moderna. Santiago de Chile. Ilustre municipalidad de Pudahuel.

Mollenkopf, J. (1992). A Phoenix in the Ashes: The Rise and Fall of the Koch Coalition in New York City Politics. Princeton, N.J.: Princeton University Press.

Naranjo, G. (2006). Efectos del Plan Regulador Metropolitano de Santiago en el Ordenamiento de los Espacios Periurbanos. In H. Capel \& R. Hidalgo (Eds.), Construyendo la Ciudad del Siglo XXI. Retos y Perspectivas Urbanas en Espana Chile. GEOlibros 6. Instituto de Geografía, Pontificia Universidad Católica de Chile.

Orozco, H., \& Vicencio, K. (2015). Desarrollo urbano condicionado y el desarrollo sustentable de Santiago. Un caso de "greenwash urbano" en los instrumentos de planificación territorial.

Schuster, J.M. (1995). Two urban festivals: La Mercè and first night. Planning Practice \& Research, 10(2), 173-188.

Stone, C.N. (1989). Regime Politics Governing Atlanta 1946-1988. Kansas: University Press.

Stone, C.N. (2001). The Atlanta Experience Re-examined: The Link between Agenda and Regime Change. International Journal of Urban and Regional Research, 25(1), 20-34.

Stone, C.N. (2005). Looking Back to look forward, Reflections on Urban Regime Analysis. Urban Affairs Review, 40(3), 309-341.

$\mathrm{Su}, \mathrm{X}$. (2010). Urban Conservation in Lijiang, China: Power structure and funding systems. Cities, 27, $164-171$.

Sur Profesionales. (2010). La labor de la Comisión Mixta en la elaboración del Plan regulador Comunal de Pudahuel. Santiago de Chile. Corporación de Desarrollo Sustentable de Pudahuel.

Thornley, A., \& Newman, N. (2005). Planning World Cities: Globalization and Urban Politics. New York: Palgrave Macmillan.

Vicuña del Río, M. (2013). El marco regulatorio en el contexto de la gestión empresarialista y la mercantilización del desarrollo urbano del Gran Santiago, Chile. Revista Invi, 28(78), 181-219.

Vicuña Del Río, M. (2017). Planificación metropolitana de Santiago: Cambios de estilo frente a las recientes transformaciones urbanas. Revista Iberoamericana de Urbanismo, (13), 47-64.

Viesti, G. (2002). Economic Policies and Local Development: Some Reflections. European Planning Studies, 10(4), 467-481.

Wolman, H., \& Goldsmith, M. (1992). Urban Politics and Policy: A comparative approach. Cambridge Massachusetts: Blackwell Publications.

\section{APPENDIX 1}

\section{Interviews}

- Mr. Bresciani, Luis Eduardo, Architect, Director Nacional de la División de Desarrollo Urbano del MINVU y Secretario Ejecutivo de la Reforma Urbana, in Santiago de Chile. Interview conducted at Santiago, interviewed on 22 July, 2010.

- Mr. Echenique, Marcial, Architect, Professor of Land Use and Transport Studies, University of Cambridge, Department of Architecture, Cambridge, UK. Interview conducted at London, interviewed on 4 August 2010.

- Mr. Julio Fernandez Soto, Director of local Real Estate Company, relevant business leader during the coalition, and founder of Codesup, interviewed on 6 August, 2010.

- Mr. Marin, Luis, Sociologist, Director Ejecutivo de Codesup, Head office in Pudahuel, Santiago de Chile. Interview conducted at Santiago, interviewed on 5 March 2009.

- Mr. Marin, Luis, Sociologist, Director Ejecutivo de Codesup, Head office in Pudahuel, Santiago de Chile. Interview conducted at London, interviewed on 2 June 2010. 
- Mr. Meza, Jorge, Diretor of Secretaria de planificación, SECPLAN, of the Ilustre Municipalidad de Pudahuel, Pudahuel, Santiago de Chile. Interview conducted at Santiago, interviewed on 15 July 2010.

- Mr. Molina, Miguel, Local community leader, and driver of the Juzgado de Policia Local de Pudahuel, Pudahuel, Santiago de Chile. Interview conducted at Santiago, interviewed on 15 July 2010.

- Mr. Torres, Enrique, Historian, former resident of Pudahuel, and benefited by educational programs implemented during the Comision Mixta de Pudahuel between 1994-2000. interviewed on 12 August 2010.

\section{APPENDIX 2}

Ten points of Nancy Holman's Urban Regime Analysis framework: (Holman N.: Journal of Urban Affairs. Vol29/No.5/2007)

1. A long-term set of arrangements or relationships by which an informal network of local actors from both the public and private sectors and possibly voluntary and/or other organizations make some governing decisions for their community.

2. There is an agenda, purpose or vision that is strongly defined.

3. Dynamic actors are able to recognize and act upon the unique attributes of their locale (John, 2001, p. 52).

4. Mobile capital and external resources are sought in order to achieve a positive sum outcome for the city.

5. Collaboration produces outcomes that would not be attainable by remaining independent.

6. Co-operation within the network is built on relationships of trust (often existing prior to the regime) and is a negotiation of individual preferences. It is what brings actors to the table.

7. Complementary resources, i.e., relevant skills, experience and adequate finances along with congruent goals, help to shape and strengthen the nature of the arrangements.

8. The arrangements are reinforced by complementary networks of agencies and participation of coalition actors within those agencies such that business interests are relatively integrated.

9. The coalition is not formally within the institutionalized structure of local government although some of its members will be and it will often act on behalf of or in co-ordination with those institutions.

10. Selective incentives may enter into negotiations. 